\title{
Impacts of Terrorism in the United Kingdom and Europe on Tourism in the United Kingdom
}

\author{
Lijuan Mao* \\ Graduate School, University of Chinese Academy of Social Sciences, Beijing, China \\ Email: *maoljuan@foxmail.com
}

How to cite this paper: Mao, L. J. (2019). Impacts of Terrorism in the United Kingdom and Europe on Tourism in the United Kingdom. Advances in Applied Sociology, 9, 491-504.

https://doi.org/10.4236/aasoci.2019.911036

Received: July 4, 2019

Accepted: November 1, 2019

Published: November 4, 2019

Copyright $\odot 2019$ by author(s) and Scientific Research Publishing Inc. This work is licensed under the Creative Commons Attribution International License (CC BY 4.0).

http://creativecommons.org/licenses/by/4.0/

(c) (i) Open Access

\begin{abstract}
Terrorist attacks occur more and more frequently. Therefore, people from all over the world pay more and more attention to them. This paper will focus on the relationship between terrorism and tourism in the United Kingdom, especially focusing on the relationship between terrorism in the United Kingdom or in Europe and tourism in the United Kingdom. This paper applies the Auto Regressive Distributed Lag (ARDL) model to figure out their relationship. The data used in this article are from the website of the United Kingdom's office for national statistics and the website of the global terrorism database respectively. Firstly, using the ADF test to figure out whether all these three variables, tourists arrivals, terrorist attacks happened in the U.K. and terrorist attacks happened in Europe continent, are stationary. Secondly, use the ARDL model to test whether terrorism in the United Kingdom and Europe respectively has an impact on British tourism. The results show that terrorism in the United Kingdom has a negative impact on British tourism while terrorism in Europe has a positive impact on it. The results are unexpected. Then analyzing the reasons why terrorism in Europe has a positive impact on tourism in the United Kingdom. But whether these reasons are true needs to explore furtherly.
\end{abstract}

\section{Keywords}

Terrorism, Tourism, United Kingdom, Europe, ARDL Model

\section{Introduction}

According to the global terrorism database, terrorist attacks happen more and more frequently. One of the most influential terrorist attacks is the September 11th attacks happened in Washington D.C. But the very first terrorist attack can be traced back to the 1970s. Terrorist attacks have occurred all over the world 
over the years, including the suicide bombing of the London bus system in the United Kingdom in 2005, explosions in Paris in 2015.

The occurrence of terrorist attacks not only leads to the death of many innocent citizens but also make a disastrous impact. Its happening put people into a worrisome situation so as to interfere tourism development of a nation or a city. Because tourists are afraid of these horrible things happening to them, they dare not travel there. At present, there are quite a lot of articles studying British tourism, which are mainly related to economy, culture, policy, the development of a specific city or a certain type of tourism destination. There are quite many articles focusing on the relationship between crises or terrorist attacks and tourism (see Gil-Alana, Mervar, \& Payne, 2015; Narayan, 2008; Liu \& Pratt, 2017; Raza \& Jawaid, 2013 among many others). There are also some researches focusing on the impact of terrorist attacks on a country or region (see Goodrich, 2002; Pizam \& Fleischer, 2002; Pizam, 1999; Chu, 2008 among many others). However, there is still no research conducting into the relationship between terrorism and tourism in the United Kingdom. Studying the relationship between them is helpful to policy-making and minimizes the impact of terrorist attacks on tourism destinations.

Figure 1 shows the trend of the number of inbound tourists. The tendency of tourist arrivals in the United Kingdom is an upward trend throughout all these years. There were significant decreases only in 1991, 2001 and 2008-2009. Why these years have a downward trend? It may be influenced by several global issues, the collapse of the Soviet Union in 1991, the September 11 attack in 2001 and the global financial crisis in 2008. However, there are continuous terrorist attacks, no matter big or small, happening in both the United Kingdom and the European continent from 1986 to 2017. Do these incidents have any impacts on tourism in the United Kingdom? This paper will carry out further research on this problem.

The structure of this paper is as follows: Chapter 1 is Introduction. Then is the

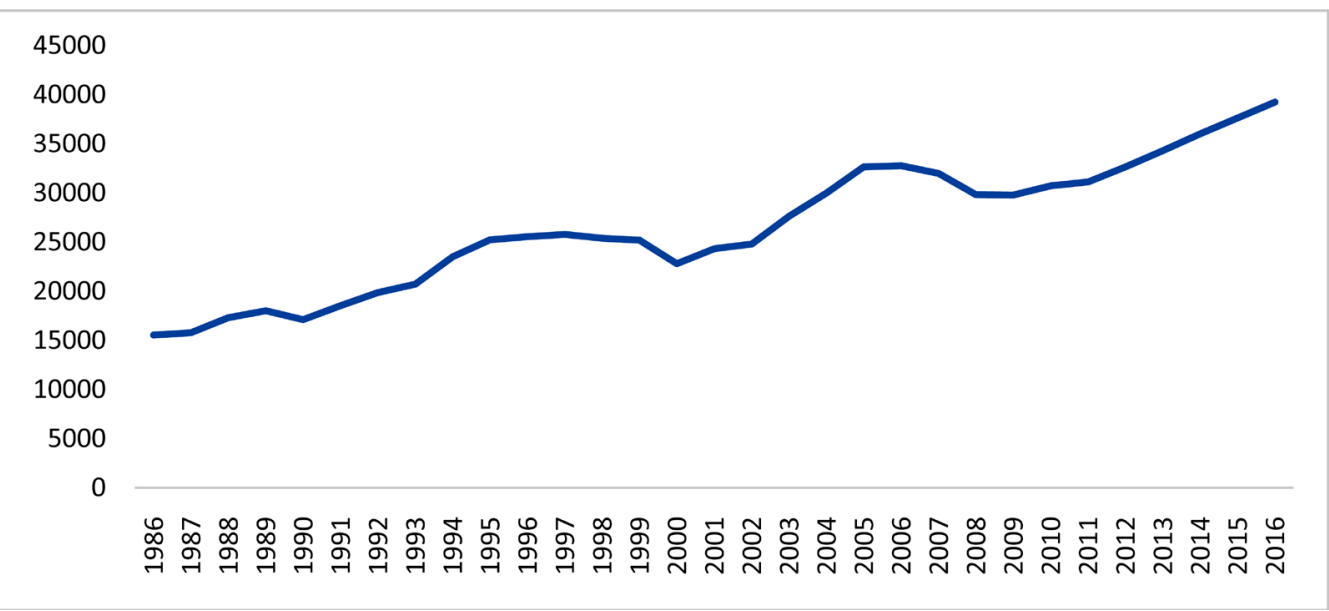

Note: the blue line represents numbers of tourism arrivals to the United Kingdom

Figure 1. Trends of tourism arrivals in the UK and Europe. 
Literary Review part, in which part the research progress of this topic is summarized after reading relevant literature. The third part is Data and Methodology, in which the research object and method are discussed. The fourth part is divided into two parts, the first shows the estimated results and the second discusses why are these results. The fifth part shows the paper's major findings, implications and some recommendations for future research.

\section{Literature Review}

\subsection{Research on Tourism}

The range of research on tourism is wide, including cultural tourism (Richards, 2018), sustainable development (Tölkes, 2018), volunteer tourism (Wearing \& McGehee, 2013), urban tourism (Cohen \& Hopkins, 2019) and so on. There are also many researchers devoting themselves in exploring factors having impacts on tourism demand (see Dritsakis, 2004; Chaisumpunsakul \& Pholphirul, 2018; Stauvermann \& Kumar, 2017 among many others). Dritsakis (2004) used the data of tourist arrivals, real income per capita, transportation cost and the real exchange rate of demand as key variables to examine tourism demand for Greece. Chaisumpunsakul \& Pholphirul (2018) found international trade as an important factor affecting inbound tourism demand. Stauvermann \& Kumar (2017) included economic growth and the increase in labor productivity as factors that promoting tourism demand. Saha \& Yap (2014) recruited a set of panel data from 139 countries from 1999-2009 to analyze whether political instability and terrorism as factors affecting tourism. They characterized that the political instability factor is much more significant than one-off terrorist attacks. While the two factors working together can seriously damage the tourism demand. Terrorist attacks actually increase the tourism demand in those much safer countries.

There are a lot of research papers based on British tourism. The themes of British tourism mainly focus on tourist behavior, tourism demand, tourism impact and so on in recent years (see Thurnell-Read, 2012; Cater, 2017; Curtin, 2013; Jarvis, Weeden, \& Simcock, 2010 among many others). Some researchers focus on tourism behavior, such as the behaviors of British single men traveling to Poland (Thurnell-Read, 2012). Cater (2017) discuses the travel pattern, travel motivation of tourists who travel by motorcycles, and its potential economic impacts. Some researchers explored tourism demand, for instance, Curtin (2013) studied the non-consumption wildlife tourism market in the United Kingdom and believed that it still had great potential. As long as the destination does good marketing, it can attract more tourists.

There are also some investigating the transportation patterns of tourism, Lyons, Jain, \& Holley (2007) studied the behaviors of tourists by different vehicles by a questionnaire survey to determine whether the travel time being saved can be effectively converted into economic valuable time. Moreover, there are some focusing on factors which affect tourism, for example, whether climate change 
would change the British tourism industry? Giles \& Perry (1998) used a temporal analog method to discuss the relationship between climate change and tourism in the United Kingdom. Jarvis et al. (2010) took the green tourism business plan in the west of Britain as an example to illustrate the benefits and challenges brought by sustainable tourism certification to tourism suppliers. As a result, there are quite a lot of papers focusing on British tourism, but researchers pay little attention to terrorism impacts on tourism in the United Kingdom.

\subsection{Terrorism and Tourism}

There are various definitions of tourism among different governments and institutions. The US Department of State defined terrorism as "premeditated, politically motivated violence perpetrated against non-combatant targets by subnational groups or clandestine agents" and international terrorism as "involving citizens or the territory of more than one country" (Annual Country Reports on Terrorism, 2010). Agnew (2010: p. 132) defined terrorism as "the commission of criminal acts, usually violent, those target civilians or violate conventions of war when targeting military personnel; and that are committed at least partially for social, political, or religious ends". He concluded that terrorism is most likely to happen when people undergo "collective strains". "Collective strains" includes material scarcity, territorial, ethical, religious and political disputes, and so on. Callaway \& Harrelson-Stephens (2006) attributed the rise of terrorism to three different kinds of human rights, including political and civil rights, security rights and subsistence rights.

There are quite a few researches relating to terrorism in the United Kingdom. Rooij, Goodwin, \& Pickup (2015) discussed how a large-scale riot in 2011 affected British citizens' prejudice against Muslims, Blacks and eastern Europeans. This research indicated that riots would strengthen prejudice against them. Gascó, Bayerl, Denef, \& Akhgar (2017) also took the riots in 2011 as an example to investigate how crisis spread during the urgent period. Although there are not many articles on terrorism in Britain, many other countries and regions, especially in Islamic regions, have quite a lot of researches in this theme. For example, Al-Dahash, Kulatunga, \& Amaratunga (2014) evaluated the level of Iraq's response to disasters and crises caused by civil war and terrorism.

There are also many pieces of research relating to the relationship between tourism and terrorism among different countries or regions (see Goodrich, 2002; Pizam \& Fleischer, 2002; Pizam, 1999; Chu, 2008 among many others). Goodrich (2002) used the September 11 terrorist attack as a case study and analyzed its impact on the tourism industry in the USA. Pizam \& Fleischer (2002), as well as Pizam (1999) resulted that terrorism with high frequency but whatever degree of severity had a much greater negative impact on tourism demand than a high severity but low frequency. If the terrorist attacks happen frequently and no matter how severe they are, the tourism demand will gradually decline and eventually 
enter an era of stagnation. This results from tourism demand data in Israel between May 1991 and May 2001. Chu (2008) tried to forecast tourism demand by using fractionally integrated ARMA model and the Asian financial crisis and the September 11 terrorist attack as examples of economic and political shocks. Athanasopoulos \& Hyndman (2008) used a regression framework to identify the influence of the Sydney Olympics in 2000 and the bombings in Bali in 2002 on domestic tourism demand in Australia. They found that the Sydney Olympics promoted an immediate demand in business travel, whereas the number of visitors meeting friends and relatives increased significantly after the blast in Bali.

Richter \& Waugh (1986) was the first to explore the relationship between them and believed that tourism and terrorism are logical companions. The political and economic impact of terrorism on tourism is assessed, including the sensitivity of the tourism industry to general political strife and the vulnerability of travellers and tourist facilities to terroristic activity in this paper. Some researchers believe there's a long-term relationship between them (see Gil-Alana et al., 2015 among many others). Gil-Alana et al. (2015) revealed that there is a persistent impact of crisis events on most of the Croatian coastal countries by using both parametric and semi-parametric fractional integration approaches.

Some others believe there's only a short-term relationship between them (see Narayan, 2008; Liu \& Pratt, 2017 among many others). Narayan (2005) applied the Sen-test to find out the structural break and that the political coups in Fiji in 1987 had a short term effect on tourist arrivals. In another research by Narayan (2008), he also got the same result that tourist arrivals to Australia were stationary no matter what kind of crisis events had happened. It means that these events only have a transitory impact on destinations. Liu \& Pratt (2017) found out that tourism is resilient to terrorism which only has a limited impact on tourism in short term.

There are also researchers who believe that there are both long-term and short-term relationships between them (see Raza \& Jawaid, 2013 among many others). Raza \& Jawaid (2013) used the Johansen and Jeuselius and ARDL (autoregressive distributed lag) bound testing cointegration approaches to investigate terrorism's impact on tourism in Pakistan between 1980 and 2010. It suggested that there are both transitory and permanent negative impacts on tourism by terrorist attacks.

But Arana and Leon thought there's no specific relationship between them. Terrorism attacks could decrease the utility of tourists and damage the image in some destinations, while some others were upgraded by surveying the shortterm impacts of the September 11 terrorist attack on the Mediterranean and the Canary Islands.

All this research shows that there may have a relationship between tourism and terrorism. But what about in the United Kingdom? This research will focus on the relationship between terrorism and tourism in the United Kingdom. Do 
the terrorist attacks in the United Kingdom have any impact on tourism in the United Kingdom? Although the United Kingdom is an island country, it is closely linked to the European continent and is also a member of the European Union (although it has voted to leave the European Union). Will the terrorist attacks in the European continent have any impact on Britain's tourism?

\section{Data and Methodology}

This section briefly introduces data sources and the methods adopted in this study. The results obtained by using the model and its analysis will be elaborated in the next section.

\subsection{Data Resources}

The data used in this paper are all secondary data. Among which, the data of overseas tourist arrivals in the United Kingdom comes from the website of the British office for national statistics: https://www.ons.gov.uk/. The data of the frequency of terrorist attacks in Great Britain and Europe comes from the global terrorism database: https://www.start.umd.edu/gtd/, which is an open-source database including information on terrorist events around the world from 1970 through 2017 (with annual updates planned for the future). Specific data are shown in Figure 1, in which the changes in the frequency of terrorist attacks in the UK and European countries (excluding the United Kingdom) from 1986 to 2017 are shown, as well as the trend of the number of inbound tourists. The data of this study were 31 years from 1986 to 2017. The unit of "the overseas tourist arrival in the United Kingdom" variable is thousand people.

Terrorist attacks are divided into two categories in this research, one is the terrorist attacks in the United Kingdom, the other is the terrorist attacks in the European continent. Although the United Kindom is the part of Europe, it is isolated from the Europe continent, the terrorism attacks in the U.K. and the European continent may have different impacts on the U.K.'s tourism. This research studies the impacts of these two kinds of terrorist attacks on tourism in the United Kingdom. These two terrorism variables are dummy variables. The variable is 1 when terrorist attacks happened, otherwise the variable is 0 . In addition, all the test results in this paper are obtained through statistical software Eviews.

\subsection{Methodology}

There are many factors affecting tourism, the impacts of terrorist attacks may not be as important as the major factors such as economic factors, distance factors, cultural factors, etc. If we use traditional regression models, the impacts of terrorist attacks maybe too small to be noticed, and the collecting data of all the other factors are not available, as a result, the Auto Regressive Distributed Lag (ARDL) model is adopted in this paper to study the impact of terrorist attacks on tourism isolatedly. The ARDL model in this research is as follows: 


$$
\begin{aligned}
\text {TOR }_{t}= & \alpha+\gamma t+\sum_{i=1}^{p=4} \Phi_{i} T O R_{t-i}+\sum_{i=0}^{p=0} \beta_{i} T E R_{-} U K_{t-i} \\
& +\sum_{i=0}^{p=1} \gamma_{i} T E R_{-} E_{\text {UROPE }}+v_{t-i}
\end{aligned}
$$

In this model, there are three variables, $T O R_{t}$ is the number of overseas tourist arrivals in the United Kingdom at time $t, T R_{t-i}$ is the lagged variable of TOR, TER_UK $K_{t-i}$ is terrorist attacks happen or not in the United Kingdom at time $t-i$, if happened TER_UK $K_{t-i}=1$ while TER_UK $K_{t-i}=0$, and $T E R R_{-} E U R O P E_{t-i}$ is terrorist attacks happen or not in the European continent at time $t-i$, if happened TER_EUROPE $E_{t-i}=1$ while TER_EUROPE $E_{t-i}=0$. $\gamma, \Phi_{i}, \beta_{i}, \gamma_{i}$ are the coefficients of TOR thi $_{1}, T E R_{-} U K_{t-i}, T E R_{-}$EUROPE $E_{t-i}$ separately, $\alpha$ is the constant, $v_{t}$ is pure white noise error term.

Since the data used in this paper are time series, Augmented Dickey-Fuller (ADF) unit root test is needed to determine the stationarity of data before the ARDL model is applied. If the data is non-stationary, it needs to be processed first. The methods used in the paper are introduced briefly in the following.

After the ADF test, we can get the result if the variables are stationary. As long as variables are integrated of the same order or they are integrated of the same order after processing, they can be applied with ARDL model to figure out if there is persistent equilibrium relationship between variables (Pesaran \& Shin, 1998) and what kind of relationship between them. Advantages of ARDL model include it is able to estimate small samples very well and it is also able to estimate endogenous variables. The ARDL model is as follows:

1) if $Y_{t}, X_{1 t}, X_{2 t}, \cdots, X_{K t}$ is integrated of order $0, I(0)$, which means they are all stationary sequence, then $\operatorname{ARDL}\left(p, q_{1}, q_{2}, \cdots, q_{k}\right)$ with $k$ variables is as follows:

$$
Y_{t}=\alpha+\gamma_{t}+\sum_{i=1}^{p} \Phi_{i} Y_{t-i}+\sum_{j=1}^{k} \sum_{l_{j}=0}^{q_{j}} \beta_{j l_{j}} X_{j, t-l_{j}}+v_{t}
$$

2) If $Y_{t}, X_{1 t}, X_{2 t}, \cdots, X_{K t}$ is integrated of order $1, I(1)$, which means the first difference of all variables $\Delta Y_{t}, \Delta X_{1 t}, \Delta X_{2 t}, \cdots, \Delta X_{k t} \sim I(0)$. then $\operatorname{ARDL}\left(p, q_{1}, q_{2}, \cdots, q_{k}\right)$ with $k$ variables is as follows:

$$
\Delta Y_{t}=\alpha+\gamma_{t}+\sum_{i=1}^{p} \Phi_{i} \Delta Y_{t-i}+\sum_{j=1}^{k} \sum_{l_{j}=0}^{q_{j}} \beta_{j l_{j}} \Delta X_{j, t-l_{j}}+v_{t}
$$

$\alpha$ represents the intercept term; $t$ represents a trend over time if there is any; $\Phi_{i}$ is explained as the coefficients of $Y_{t-i}$, which is the lagged term of $Y_{t}$; $p$ represents how many lagged terms do $Y_{t}$ have; $\beta_{j l_{j}}$ represents the coefficients of $\Delta X_{j, t-l_{j}} ; q_{j}$ represent how many lag terms do $X_{j, t}$ have; $k$ represents the number of explanatory $X_{j, t} ; v_{t}$ is pure white noise error term. The null hypothesis $\left(\mathrm{H}_{0}\right)$ for all three models is $\Phi_{i}=\beta_{j l_{j}}=0$, which means there is no relationship between the variables.

\section{Estimated Results and Discussion}

The previous chapter briefly introduces the econometric knowledge involved in this study. This chapter is divided into two parts, the first shows the estimated results obtained from the ARDL model while the second discusses the meanings 
of these results and the reasons for such results.

\subsection{Estimated Results}

\subsubsection{Results of ADF Test}

According to the theory introduced in chapter 3, the ADF test is the first step to do the research. The results are shown in Table 1 and Table 2. Table 1 shows that these three variables together are stationary, that is $I(0)$, no matter by using ADF-Fisher Chi-square or ADF-Choi Z-stat method. Because we can see that the probability of either ADF-Fisher Chi-square or ADF-Choi Z-stat method is 0.00 which is smaller than 0.05 , the null hypothesis is rejected. Table 2 shows that these three variables respectively are stationary. The probabilities of variable "TER_EUROPE", “TER_UK" and "TOR" are $0.0010,0.0001$ and 0.0038 respectively. They are all much smaller than 0.05 , as a result, the null hypothesis is rejected. These results indicate that there may be a long-term equilibrium relationship between variables, but whether it exists or not needs to be verified by ARDL model.

\subsubsection{Results of ARDL Model}

From the results of the ADF test, we know that all these three variables are integrated of the same order. Therefore the variables satisfy the precondition of ARDL modeling. Whether there is a long-term relationship between terrorism and tourism in the United Kingdom can be tested by ARDL model, as well as the specific relationship between tourism and terrorist attacks in the UK, tourism and terrorist attacks in the European continent.

The results of the ARDL model are shown in Table 3. The results reject the null hypothesis which means there is a long-term relationship between variables since the probability of F-statistic is 0.00 which is smaller than 0.05 . Terrorist attacks in the United Kingdom do have a long-term relationship with tourism in the United Kingdom, as well as terrorist attacks in the European continent.

All variables' optimal lag numbers in the ARDL model are determined by

Table 1. ADF test results 1.

\begin{tabular}{ccc}
\hline Method & Statistic & Prob. $^{* *}$ \\
\hline ADF-Fisher Chi-square & 43.4995 & 0.0000 \\
ADF-Choi Z-stat & -5.48273 & 0.0000 \\
\hline
\end{tabular}

Note. ${ }^{*}$ Probabilities for Fisher tests are computed using an asymptotic Chi-square distribution. All other tests assume asymptotic normality.

Table 2. ADF test results 2 .

\begin{tabular}{ccccc}
\hline Series & Prob. & Lag & Max Lag & Obs \\
\hline TER_EUROPE & 0.0010 & 0 & 6 & 31 \\
TER_UK & 0.0001 & 0 & 6 & 31 \\
TOR & 0.0038 & 2 & 6 & 29 \\
\hline
\end{tabular}


Table 3. Results of the ARDL model.

\begin{tabular}{ccccc}
\hline Variable & Coefficient & Std. Error & t-Statistic & Prob. $^{* *}$ \\
\hline TOR $(-1)$ & 0.765359 & 0.205429 & 3.725668 & 0.0014 \\
TOR $(-2)$ & 0.186031 & 0.232972 & 0.798512 & 0.4344 \\
TOR $(-3)$ & -0.201005 & 0.248580 & -0.808614 & 0.4287 \\
TOR $(-4)$ & -0.505203 & 0.248612 & -2.032094 & 0.0564 \\
TER_EUROPE & 1056.515 & 329.7762 & 3.203732 & 0.0047 \\
TER_ERUOPE $(-1)$ & 701.2164 & 477.8714 & 1.467375 & 0.1586 \\
TER_UK & -975.1260 & 440.0060 & -2.216165 & 0.0391 \\
$\alpha$ & 10495.25 & 2336.755 & 4.491377 & 0.0003 \\
$\gamma$ & 499.8152 & 111.0961 & 4.498946 & 0.0002 \\
R-squared & 0.988858 & Mean dependent var & 27627.75 \\
Adjusted R-squared & 0.984167 & S.D. dependent var & 5965.448 \\
S.E. of regression & 750.6292 & Akaike info criterion & 16.33479 \\
Sum squared resid & 10705438 & Schwarz criterion & 16.76300 \\
Log likelihood & -219.6871 & Hannan-Quinn Criterion & 16.46570 \\
F-statistic & 210.7866 & Durbin-Watson stat & 2.018442 \\
Prob (F-statistic) & 0.000000 & & \\
\hline
\end{tabular}

Note. P-values and any subsequent tests do not account for model selection.

Eviews automatedly. As shown in Table 3, the optimal lag numbers are 4, 1 and 0 respectively, that is $\operatorname{ARDL}(4,1,0)$, which means variable "TOR" has a forth lag term, variable "TER_UK" has no lag term, and variable "TER_EUROPE" has a first lag term. The coefficients of variable "TOR", "TER_UK" and "TER_EUROPE” estimated by ARDL model are shown in Table 3. The equation with these coefficients is shown as follows:

$$
\begin{aligned}
\text { TOR }_{t}= & 10495.25+499.82 \gamma+0.77 T^{2} R_{t-1}+0.19 \text { TOR }_{t-2}-0.20 T O R_{t-3} \\
& -0.50 T O R_{t-4}-975.13 T E R_{-} U K_{t}+1056.52 T E R_{-} E U R O P E_{t} \\
& +701.22 T E R_{-} E U R O P E_{t-1}+v_{t}
\end{aligned}
$$

\subsection{Discussion}

Reviewing the research questions of this paper, the first question is whether terrorist attacks in the United Kingdom have any impacts on tourism in the United Kingdom? The second question is whether terrorist attacks in the European continent have any impact on tourism in the United Kingdom? These two questions have been solved according to the estimated results. Both terrorist attacks in the United Kingdom and the European continent have impacts on inbound tourism in the United Kingdom. But the direction and extent of their impacts are different.

The impact of terrorist attacks in the United Kingdom on tourism in the United Kingdom: From the coefficients of variables in Table 3, we can know that the impact of terrorist attacks in the United Kingdom on tourism in the 
United Kingdom is contemporaneous without any lag terms, and is negative. Since variable "TER_UK $K_{t-i}$ ” is a dummy variable which indicates if there are any terrorist attacks in the United Kingdom, that is $T E R R_{-} U K_{t-i}$ equals 1, overseas tourism arrivals to the United Kingdom will be reduced by 975,126 in that year.

The impact of terrorist attacks in the European continent on tourism in the United Kingdom is not only positive in the contemporaneous period, but also in the previous period. The variable "TER_EUROPE ${ }_{t}$ " is also a dummy variable, it only has two values: 0 and 1. According to the results in the Equation (7), When $T E R \_E U R O P E_{t}$ equals 1 , which means when there are any terrorist attacks in the European continent, overseas tourism arrivals to the United Kingdom will be increased by 1056,515 in that year. If there are any terrorist attacks in the European continent in the previous year, which means TER_EUROPE $E_{t-1}=1$, overseas tourism arrivals to the United Kingdom will be increased by 701,216 in that year.

These results are different from what was expected. Surprisingly, the impact of terrorist attacks on the European continent on tourism in the United Kingdom is positive. But why is this result?

Firstly, it indicates that the image of Great Britain as a tourism destination is separated from that of the European continent. Terrorist attacks happening in the European continent won't change the image of Great Britain in tourists' minds. This is mainly because of the geographically separate of the United Kingdom and the European continent. What's more, the United Kingdom is neither a Eurozone nor a Schengen country, though the United Kingdom is one of the European Union (EU) countries. As a result, once terrorist attacks occur in the European continent, overseas travelers will prefer traveling to the United Kingdom, especially those from EU countries. They will tend to travel outside the Schengen countries but close to them geographically and rich in tourism resources. The best choice for them is the United Kingdom.

Secondly, there are various types of tourists, such as conference tourists, leisure tourists, family visit tourists, and so on. Different tourists have different degrees of response to terrorist attacks. Some tourists (such as conference tourists) have a large demand elasticity in tourism destination while others (such as tourists for visiting relatives) have a small demand elasticity. Once terrorist attacks happen, those having a large demand elasticity in tourism destination will choose another destination for replacing. For example, those conference organizers will move the venues to the United Kingdom which is relatively safer but not far. As a result, the number of overseas tourists arrivals to the United Kingdom will increase.

\section{Conclusion}

\subsection{Major Findings}

The research discusses the impact of terrorist attacks on British tourism by using 
ARDL model. The results show that terrorist attacks in the United Kingdom have a positive impact on tourism in the United Kingdom, while terrorist attacks in the European continent have a negative impact on British tourism. What's more surprising, the impact of terrorist attacks in the European continent on tourism in the United Kingdom is not only positive in the contemporaneous period, but also in the previous period.

\subsection{Implications}

Terrorist attacks in different regions have different impacts on British tourism. The reason for this may result from the separate of tourism image of the United Kingdom and the European continent. As a result, the impact of terrorist attacks in the European continent is different from that of the United Kingdom. And because of the occurrence of terrorist attacks in the European continent, some categories of tourists with flexible tourism demand shift their tourist destinations from the European continent to island country-the United Kingdom. This leads to an increase of overseas tourism arrivals to the United Kingdom. The results of this research can be used as a theoretical basis for policymaking. It may help reduce the impact of terrorist attacks after terrorist attacks and accelerate the reconstruction of the destination image.

This research determines whether there is a relationship between terrorism and tourism and if there is any relationship and what kind of relationship between them by using the ARDL model. In fact, there are many factors influencing tourism, such as the economic development level of tourism destination, per capita disposable income, cultural preference, accessibility to a tourist destination and so on. If all influencing factors are included, the regression equation will be very enormous. Let alone there are some important variables that may be ignored. The influencing coefficient of terrorism will be very small by using this kind of regression. Moreover, data of many influencing factors are not available. Therefore, the ARDL model is more direct and convenient to determine whether there is a certain relationship in variables, compared with simple multiple regression. This method is equivalent to controlling all other variables, as long as the data of variables are stable, or stable after processing.

\subsection{Limitations and Recommendations for Future Research}

There still have many areas that can be further improved. Firstly, the definition of the terrorism attacks is not accurate enough, I am not sure if the terrorism attacks included in this paper is correct. Secondly, the result can only apply to the United Kingdom according to the specific data and the specific location of the United Kingdom.

Terrorist attacks are divided into two categories in this research, one is the terrorist attacks in the United Kingdom, the other is the terrorist attacks in the European continent. This research studies the impacts of these two kinds of terrorist attacks on tourism in the United Kingdom. My original assumption was 
that the terrorist attacks' influencing is less if the place is further. However, terrorist attacks' impacts on British tourism is not positively correlated with distance according to the estimated results. What's more, the decrease of overseas tourism arrivals in the United Kingdom in 2001 is due to the September 11 attack (see Figure 1). Therefore, if any further research is needed, the origin of terrorist attacks can be expanded.

Secondly, the impact of terrorist attacks on the European continent on British tourism is positive according to the estimated results. Such a result is likely when there's a significant increase in the number of several certain categories of tourist arrivals. As analyzed before, a certain kind of category may be conference tourism. However, this research does not verify if there is any different impact among different tourists. If further research is needed, new ARDL models can be built by using data of the different type of tourists to determine if there are different impacts and which categories are the most affected.

Thirdly, a terrorist attack is one kind of crisis. The crisis also includes natural disasters such as earthquakes, political events, financial crisis and so on Athanasopoulos \& Hyndman (2008) identified the influence of the Sydney Olympics in 2000 and the bombings in Bali in 2002 on domestic tourism demand in Australia. According to their results, they conducted some suggestions on how to recover quickly after being affected. Therefore, terrorism can be expanded to the crisis to further study the impact of the crisis on British tourism.

Fourthly, as can be seen from Figure 1, the number of overseas tourist arrivals to the United Kingdom is continuous increasing apart from several specific years, 1991, 2001, 2008 and 2009. Terrorist attacks occur from time to time besides these specific years, but the number of overseas tourism arrivals to the United Kingdom has not been greatly affected. Is it possible that the reason for this phenomenon is that the UK government has taken timely measures to prevent the decrease, such as releasing the visa difficulty? If further research is to be carried out, I think it is necessary to disentangle the impact of policy.

In general, this research has concluded that terrorist attacks in the United Kingdom have a negative impact on British tourism, while terrorist attacks in the European continent have a positive impact on it by using ARDL model.

\section{Conflicts of Interest}

The author declares no conflicts of interest regarding the publication of this paper.

\section{References}

Agnew, R. (2010). A General Strain Theory of Terrorism. Theoretical Criminology, 14, 131-153. https://doi.org/10.1177/1362480609350163

Al-Dahash, H., Kulatunga, U., \& Amaratunga, D. (2014). Evaluation of the System of Disaster Management Resulting from War Operations and Terrorism in Iraq. Procedia Economics and Finance, 18, 900-907. https://doi.org/10.1016/S2212-5671(14)01016-8

Annual Country Reports on Terrorism (2010). Title 22-Foreign Relations and Inter- 
course.

https://www.gpo.gov/fdsys/pkg/USCODE-2010-title22/html/USCODE-2010-title22.htm

Athanasopoulos, G., \& Hyndman, R. J. (2008). Modelling and Forecasting Australian Domestic Tourism. Tourism Management, 29, 19-31.

https://doi.org/10.1016/j.tourman.2007.04.009

Callaway, R., \& Harrelson-Stephens, J. (2006). Toward a Theory of Terrorism: Human Security as a Determinant of Terrorism. Studies in Conflict \& Terrorism, 29, 773-796. https://doi.org/10.1080/10576100600701974A

Cater, C. I. (2017). Tourism on Two Wheels: Patterns of Motorcycle Leisure in Wales. Tourism Management, 61, 180-189. https://doi.org/10.1016/j.tourman.2017.02.007

Chaisumpunsakul, W., \& Pholphirul, P. (2018). Does International Trade Promote International Tourism Demand? Evidence from Thailand's Trading Partners. Kasetsart Journal of Social Sciences, 39, 393-400. https://doi.org/10.1016/j.kjss.2017.06.007

Chu, F. L. (2008). A Fractionally Integrated Autoregressive Moving Average Approach to Forecasting Tourism Demand. Tourism Management, 29, 79-88.

https://doi.org/10.1016/j.tourman.2007.04.003

Cohen, S. A., \& Hopkins, D. (2019). Autonomous Vehicles and the Future of Urban Tourism. Annals of Tourism Research, 74, 33-42.

https://doi.org/10.1016/j.annals.2018.10.009

Curtin, S. (2013). Lessons from Scotland: British Wildlife Tourism Demand, Product Development and Destination Management. Journal of Destination Marketing \& Management, 2, 196-211. https://doi.org/10.1016/j.jdmm.2013.09.002

Dritsakis, N. (2004). Cointegration Analysis of German and British Tourism Demand for Greece. Tourism Management, 25, 111-119.

https://doi.org/10.1016/S0261-5177(03)00061-X

Gascó, M., Bayerl, P. S., Denef, S., \& Akhgar, B. (2017). What Do Citizens Communicate about during crises? Analyzing Twitter Use during the 2011 United Kingdom Riots. Government Information Quarterly, 34, 635-645. https://doi.org/10.1016/j.giq.2017.11.005

Gil-Alana, L. A., Mervar, A., \& Payne, J. E. (2015). Measuring Persistence in Croatian Tourism: Evidence from the Adriatic Region. Applied Economics, 47, 4901-4917. https://doi.org/10.1080/00036846.2015.1037440

Giles, A. R., \& Perry, A. H. (1998). The Use of a Temporal Analogue to Investigate the Possible Impact of Projected Global Warming on the United Kingdom Tourist Industry. Tourism Management, 19, 75-80. https://doi.org/10.1016/S0261-5177(97)00093-9

Goodrich, J. N. (2002). September 11, 2001 Attack on America: A Record of the Immediate Impacts and Reactions in the USA Travel and Tourism Industry. Tourism Management, 23, 573-580. https://doi.org/10.1016/S0261-5177(02)00029-8

Jarvis, N., Weeden, C., \& Simcock, N. (2010). The Benefits and Challenges of Sustainable Tourism Certification: A Case Study of the Green Tourism Business Scheme in the West of England. Journal of Hospitality and Tourism Management, 17, 83-93. https://doi.org/10.1375/jhtm.17.1.83

Liu, A., \& Pratt, S. (2017). Tourism's Vulnerability and Resilience to Terrorism. Tourism Management, 60, 404-417. https://doi.org/10.1016/j.tourman.2017.01.001

Lyons, G., Jain, J., \& Holley, D. (2007). The Use of Travel Time by Rail Passengers in Great Britain. Transportation Research Part A: Policy and Practice, 41, 107-120. https://doi.org/10.1016/j.tra.2006.05.012

Narayan, P. K. (2005). Testing the Unit Root Hypothesis When the Alternative Is a Trend 
Break Stationary Process: An Application to Tourist Arrivals in Fiji. Tourism Economics, 11, 351-364. https://doi.org/10.5367/000000005774352971

Narayan, P. K. (2008). Examining the Behaviour of Visitor Arrivals To Australia from 28 Different Countries. Transportation Research Part A Policy \& Practice, 42, 751-761. https://doi.org/10.1016/j.tra.2008.01.032

Pesaran, M. H., \& Shin, Y. (1998). Generalized Impulse Response Analysis in Linear Multivariate Models. Economic Letters, 58, 17-20. https://doi.org/10.1016/S0165-1765(97)00214-0

Pizam, A. (1999). A Comprehensive Approach to Classifying Acts of Crime and Violence at Tourism Destinations. Journal of Travel Research, 38, 5-12. https://doi.org/10.1177/004728759903800103

Pizam, A., \& Fleischer, A. (2002). Severity versus Frequency of Acts of Terrorism: Which Has a Larger Impact on Tourism Demand? Journal of Travel Research, 40, 337-339. https://doi.org/10.1177/0047287502040003011

Raza, S. A., \& Jawaid, S. T. (2013). Terrorism and Tourism: A Conjunction and Ramification in Pakistan. Economic Modelling, 33, 65-70. https://doi.org/10.1016/j.econmod.2013.03.008

Richards, G. (2018). Cultural Tourism: A Review of Recent Research and Trends. Journal of Hospitality and Tourism Management, 36, 12-21. https://doi.org/10.1016/j.jhtm.2018.03.005

Richter, L. K., \& Waugh, W. L. J. (1986). Terrorism and Tourism as Logical Companions. Tourism Management, 7, 230-238. https://doi.org/10.1016/0261-5177(86)90033-6

Rooij, E. A., Goodwin, M. J., \& Pickup, M. (2015). Threat, Prejudice and the Impact of the Riots in England. Social Science Research, 51, 369-383. https://doi.org/10.1016/j.ssresearch.2014.09.003

Saha, S., \& Yap, G. (2014). The Moderation Effects of Political Instability and Terrorism on Tourism Development: A Cross-Country Panel Analysis. Journal of Travel Research, 53, 509-521. https://doi.org/10.1177/0047287513496472

Stauvermann, P. J., \& Kumar, R. R. (2017). Productivity Growth and Income in the Tourism Sector: Role of Tourism Demand and Human Capital Investment. Tourism Management, 61, 426-433. https://doi.org/10.1016/j.tourman.2017.03.006

Thurnell-Read, T. (2012). Tourism Place and Space: British Stag Tourism in Poland. Annals of Tourism Research, 39, 801-819. https://doi.org/10.1016/j.annals.2011.09.009

Tölkes, C. (2018). Sustainability Communication in Tourism-A Literature Review. Tourism Management Perspectives, 27, 10-21. https://doi.org/10.1016/j.tmp.2018.04.002

Wearing, S., \& McGehee, N. G. (2013). Volunteer Tourism: A Review. Tourism Management, 38, 120-130. https://doi.org/10.1016/j.tourman.2013.03.002 